Rev. Int. Contam. Ambie. 37, 527-537, 2021

https://doi.org/10.20937/RICA.53850

\title{
HEAVY METALS BIOACCUMULATION AND RISK ESTIMATION IN EDIBLE FRESHWATER FISH FROM PEDROSO RESERVOIR (MAYABEQUE, CUBA)
}

\author{
Bioacumulación de metales pesados y estimación del riesgo de exposición por consumo de peces de \\ agua dulce provenientes de la presa Pedroso (Mayabeque, Cuba)
María A. MESA PÉREZ ${ }^{1 *}$, Oscar DÍAZ RIZO², Humberto GARCÍA ACOSTA², Onelia Adriana ALARCÓN SANTOS ${ }^{1}$, Marie J. TAVELLA ${ }^{4}$, David BAGUÉ ${ }^{4}$, José M. SÁNCHEZ-PÉREZ ${ }^{4}$, Lilisbet GUERRERO DOMÍNGUEZ ${ }^{5}$, Daylen HERNÁNDEZ RODRÍGUEZ ${ }^{1}$ and Carlos Miguel DÍAZ ALMEIDA ${ }^{6}$

${ }^{1}$ Universidad Agraria de La Habana, Carretera de Tapaste y Autopista Nacional, San José de las Lajas, Mayabeque, Cuba, C.P. 32700.

${ }^{2}$ Instituto Superior de Tecnologías y Ciencias Aplicadas, Universidad de La Habana, Av. Salvador Allende y Luaces, La Habana, Cuba, C.P. 110400.

${ }^{3}$ Empresa Provincial de Aprovechamiento Hidráulico, km 3.5 Carretera de Güines, Güines, Mayabeque, Cuba, C.P. 34310.

${ }^{4}$ Laboratoire d'Ecologie Fonctionnel et Environnemental, Université Toulouse 3, Avenue del'Agrobiopole, BP3 2607 31326, Castanet, Tolosan, Toulouse, France.

${ }^{5}$ Instituto Nacional de Ciencias Agrícolas, km 3.5 Carretera de Tapaste y Autopista Nacional. San José de las Lajas, Mayabeque, Cuba, C.P. 32700.

${ }^{6}$ Universidad de Matanzas, km 3.5 Autopista a Varadero (Vía Blanca), Ciudad de Matanzas, Matanzas, Cuba, A.P. 44740.

*Author for correspondence: mariaa@unah.edu.cu

(Received: January 2020; accepted: June 2020)

Key words: heavy metals, water, fish, bioaccumulation, food safety, Cuba.

\begin{abstract}
This work is a validation of the second step of a heavy metal monitoring procedure in Cuba fluvial ecosystems. Concentrations of seven heavy metals were measured by ICP-MS in water samples collected from the Pedroso reservoir (Mayabeque province, Cuba) and its main tributaries, as well as in edible muscle of three locally consumed fish species: Oreochromis spp., Tinca tinca and Clarias gariepinus. The results show a high concentration of $\mathrm{Pb}$ in areas near a paint factory $(85.5 \mu \mathrm{g} / \mathrm{L})$, an asphalt factory and a high traffic area $(345.8 \mu \mathrm{g} / \mathrm{L})$. Metal content (in $\mathrm{mg} / \mathrm{kg} \mathrm{ww}$ ) in fish fillet ranged as follows: $\mathrm{Cr}(0.01-0.58), \mathrm{Co}(0.01-0.58), \mathrm{Cu}$ (0.23-88.16), $\mathrm{Zn}$ (4.9-29.9), As (0.01-0.86), $\mathrm{Cd}(0.02-2.93)$ and $\mathrm{Pb}(0.01-1.23)$. According to Cuban regulations, concentrations of $\mathrm{Cd}$ in muscle are not safe in 37.5 to $44.0 \%$ of the studied fishes, while $\mathrm{Pb}$ is high in 14.0 to $20.0 \%$. Non-carcinogenic risk (HI) is present when daily intake is above $81 \mathrm{~g} /$ day. Carcinogenic risk (ELCR) is calculated to be $5.8 \times 10^{-4}$ according to the US-EPA methodology. Fishermen families are the most sensitive population sector. Local authorities were informed and different measures were taken to avoid polluted fish consumption and the reduction of pollutant sources.
\end{abstract}

Palabras clave: metales pesados, agua, peces, bioacumulación, seguridad alimentaria, Cuba. 


\section{RESUMEN}

Este trabajo constituye la validación de la segunda etapa del procedimiento de monitoreo de metales pesados en ecosistemas fluviales de Cuba y mide la concentración de siete metales pesados por ICP-MS en muestras de agua recolectadas en la presa Pedroso (provincia de Mayabeque, Cuba) y sus principales tributarios, así como en el músculo ventral de tres especies de peces utilizadas para consumo humano y animal: Oreochromis spp., Tinca tinca y Clarias gariepinus. Los resultados muestran altas concentraciones de $\mathrm{Pb}$ en áreas cercanas a la fábrica de pintura $(85.5 \mu \mathrm{g} / \mathrm{L})$, de asfalto $(85.5 \mu \mathrm{g} / \mathrm{L})$ y a la Autopista Nacional $(345.8 \mu \mathrm{g} / \mathrm{L})$. Las concentraciones de metales pesados ( $\mathrm{mg} / \mathrm{kg}$ peso húmedo) en el músculo del pescado fueron: $\mathrm{Cr}(0.01-0.58)$, Co (0.01-0.58), Cu (0.23-88.16), Zn (4.9-29.9), As (0.01-0.86), Cd (0.02-2.93) y Pb (0.011.23). De acuerdo con las regulaciones cubanas, las concentraciones de $\mathrm{Cd}$ no son recomendables para el consumo en el 37.5-44.0\% de los peces evaluados, mientras que el $\mathrm{Pb}$ es elevado en el 14-20\% de los mismos. Se presenta riesgo no carcinogénico (HI) en las poblaciones aledañas cuando el consumo de pescado contaminado alcanza los $81 \mathrm{~g} /$ día. El riesgo carcinogénico (ELCR) fue estimado en $5.8 \times 10^{-4}$ de acuerdo con la metodología de la US-EPA. Los pescadores y sus familias son la población en mayor riesgo de padecer una enfermedad crónica o desarrollar cáncer relacionado con la contaminación por metales pesados en el área. Las autoridades gubernamentales y sanitarias fueron informadas y actualmente se toman medidas para evitar el consumo de peces y disminuir el impacto de las fuentes contaminantes.

\section{INTRODUCTION}

Heavy metals are among the most common environmental pollutants and their occurrence in waters and biota indicate the presence of natural or anthropogenic sources.

The existence of heavy metals in aquatic environments has become a serious threat due to their toxicity, bioaccumulation, long persistence, and biomagnification in the food chain (Erdogrul and Ates 2006, Agah et al. 2009, Yi and Zhang 2012, Monroy et al. 2014).

The Mampostón basin is the smallest hydrological and hydrographic system $\left(157.8 \mathrm{~km}^{2}\right)$ of the Mayabeque River basin in the center of the Cuban province of the same name. It is surrounded by agricultural and livestock lands as well as by highly industrialized areas. The urbanizations of San José de las Lajas and Güines municipalities are also located nearby (Fig. 1).

This hydrographic unit was remodeled in 1970 with the construction of two artificial reservoirs: Pedroso (with a capacity of $4 \mathrm{Mm}^{3}$ ) and Mampostón $\left(150 \mathrm{Mm}^{3}\right)$. Both Mampostón river and its tributary Ganuza flow their waters (as well as their potential contaminant charge) into Pedroso reservoir. This water is pumped toward the Mampostón reservoir, which has no direct contaminant source, and it is subsequently sent to irrigate the crops in the southwest region of the most important agricultural zone of the western Cuban provinces via the artificial channel Mampostón-Güira de Melena. Furthermore, the

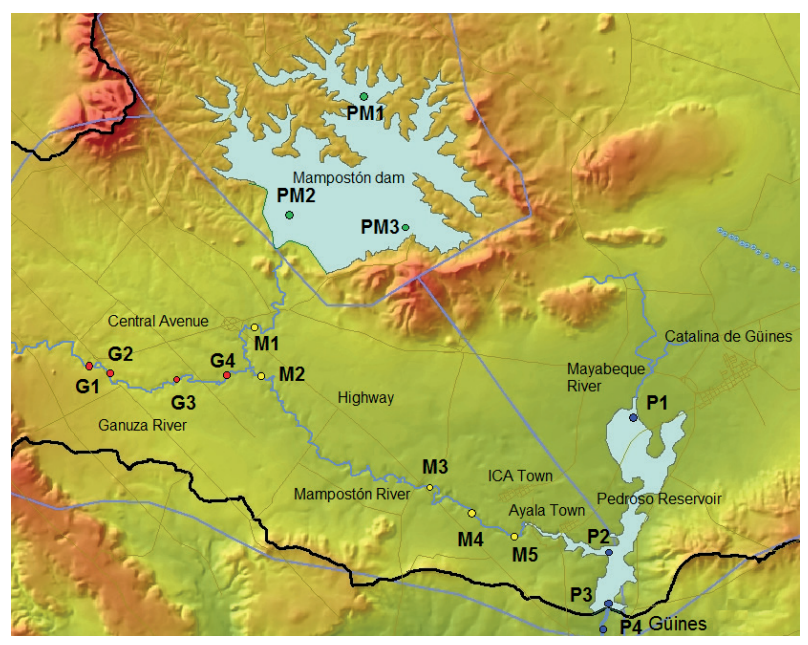

Fig. 1. Location of the studied stations in the Ganuza River $(\mathrm{G})$, Mamposton River (M) and Pedroso reservoir (P).

Pedroso reservoir has an overflow channel into the Mayabeque River and its waters are used to irrigate the sugar cane fields located on the eastside of the Mayabeque province.

On the other hand, an important aquaculture center is located on the Mampostón reservoir, focused on tilapia (Oreochromis spp.), tench (Tinca tinca) and catfish (Clarias gariepinus) farming. Fishery activities in the Mampostón reservoir are authorized, while in the Pedroso reservoir they are not. This has led to many locals to furtively capture fish from the 
Pedroso reservoir and later commercializing the product without first studying its environmental quality parameters. Therefore, the goal of the present study was to determine the heavy metal content in water samples from the Pedroso basin and its tributaries, metal accumulation in the edible muscle of the previously mentioned fish species, and the potential and real risk of different populations in the area.

\section{MATERIALS AND METHODS}

\section{Collection and analysis of water samples}

Water samples were collected at the beginning of the rainy season at 13 stations located near the previously considered potential contamination sources (Fig. 1): four stations in the Ganuza river (G1: 100 $\mathrm{m}$ north of the dairy factory, G2: $50 \mathrm{~m}$ south of the dairy factory, G3: $100 \mathrm{~m}$ south of a rum factory, and G4: $50 \mathrm{~m}$ south of paint factory); five stations in the Mampostón river (M1: $100 \mathrm{~m}$ south of an aluminum factory and $50 \mathrm{~m}$ north of an asphalt factory, M2: 50 $m$ south of an asphalt factory, M3: in the national highway bridge, M4: in a free zone, and M5: $100 \mathrm{~m}$ south of a research center); and four stations in the Pedroso reservoir (P1: Americano River flow into the reservoir, P2: Mampostón River flow into the reservoir, P3: center of the reservoir, and P4: overflow channel of the Pedroso reservoir).

Water samples were collected in the middle of the rivers or $5 \mathrm{~m}$ offshore in the reservoir, using acidwashed five-liter nonreactive plastic containers. In the laboratory, samples were first filtered through a Wacksman $70 \mu \mathrm{m}$ filter to separate the organic particulate fraction, then through a $22 \mu \mathrm{m}$ cellulose filter to separate the metallic diluted and colloidal fraction from the particulate one.

\section{Fish sampling and analysis}

Fish species were selected using two criteria: $(i)$ their consumption by local population, and (ii) their feeding behavior. Tilapia fish consume plant tissue, small fish, shrimp, detritus, and sediments, whereas tench are omnivores fishes with a diverse food spectrum, including bottom invertebrates and aquatic insect larvae. On the other hand, catfish represent the dominant predator in Cuban freshwater ecosystems, feeding off other fishes, insects, crustaceans, plankton, rotting flesh and plants, and trash fish.

Seventy-eight fishes of the studied species were captured by a local fisherman using fishing nets (ø $1 \mathrm{~cm}^{2}$ ). Fishes were captured in the Pedroso Reservoir during two months at the beginning of the rainy season. Number of samples (96), represents $10 \%$ of estimated annual fishery, around $9350 \mathrm{~kg}$ (MIP 2008).

Fishes were measured and weighted on site. Muscle tissue samples were obtained from the ventral area and the fillets were frozen at $-20^{\circ} \mathrm{C}$. Back in the laboratory, muscle samples were firstly dried at $60^{\circ} \mathrm{C}$, immersed in liquid nitrogen and macerated until fish flour was obtained. The macerated samples were again dried at $60{ }^{\circ} \mathrm{C}$ until a constant weight was obtained.

The total concentration of heavy metals was obtained by digestion mixturing $100-150 \mathrm{mg}$ of the animal's dry flour with $5 \mathrm{~mL} \mathrm{HNO}_{3} 70 \%$ and $5 \mathrm{~mL}$ $\mathrm{H}_{2} \mathrm{O}_{2} 30 \%$ (Huang et al. 2003, Wang et al. 2007). Heavy metals (Cr, Co, $\mathrm{As}, \mathrm{Cu}, \mathrm{Zn}, \mathrm{Cd}$, and $\mathrm{Pb}$ ) were determined by ICP-MS Agilent Technologies 7500 CE and HR-ICP-MS Thermo Scientific Element XR at the Observatoire Midi-Pyrénées, Toulouse, France. $\mathrm{An}{ }^{115} \mathrm{In} /{ }^{187} \mathrm{Re}$ internal standard of a known concentration $(2.032 \mu \mathrm{g} / \mathrm{L})$ were added to all samples and four quality control samples were introduced following every eight samples to correct for any analyzer deviation. All the determined concentration values were within the detection and quantification limits of the equipment $(50 \mathrm{pg} / \mathrm{g})$.

Certified materials SRLS-5 and Tort-2, from the Canadian National Water Research Institute, were used as the calibration verification standards for both water and fish muscle, respectively. For both materials, the results were: $80-89 \%$ of average recovery for $\mathrm{Cu}, \mathrm{Cd}, \mathrm{Zn}, \mathrm{Cr}$, and $\mathrm{As} ; 90-99 \%$ for $\mathrm{Pb}$ and $100-$ $110 \%$ for Co. All data were evaluated for normality using the Kolmogorov-Smirnov test and the SPSS 9.0 software. The variability between medians was established by ANOVA and Duncan. Results were considered significant if $\mathrm{p}<0.05$.

The bioaccumulation factor (BAF), which describes the concentration of a metal in water $\left(\mathrm{C}_{\mathrm{w}}\right)$ to its concentration in an aquatic animal $\left(\mathrm{C}_{\mathrm{m}}\right)$ at equilibrium, is generally used to estimate the proneness of the biota to accumulate heavy metals and it is calculated as:

$B A F=C_{\mathrm{m}} / C_{\mathrm{w}}$

where $C_{\mathrm{m}}(\mathrm{mg} / \mathrm{kg}$ ww) refers to the metal concentration in flesh and $C_{\mathrm{w}}(\mu \mathrm{g} / \mathrm{L})$ to metal concentration in water. If $B A F>1.0$, metals bioaccumulation occurs in fishes (Canpolat et al. 2014).

\section{Potential and real risk analysis}

The methodology for the estimation of excessive lifetime cancer risk (ELCR) and the hazard quotient (HI) was based in the US-EPA Region III risk-based 
concentration table (US-EPA 2006) using the formulas specified below (Ling et al. 2009):

$$
\begin{aligned}
& H Q i=\frac{\left(C i \times D I \times E F r \times E D_{H Q}\right)}{\left(C S F O \times \frac{\sqrt[3]{B W a}}{B W m S C}\right) \times B W a \times A T_{H Q} \times 10^{3}} \\
& H I=\sum H Q i=H Q_{A s}+H Q_{C u}+ \\
& H Q_{P b}+H Q_{C d}+H Q_{Z n} \\
& E L C R=\frac{\left(C \times D I \times E F r \times E D_{E L C R}\right)}{\left(C S F O \times \frac{\sqrt[3]{B W a}}{B W m S C}\right) \times B W a \times A T_{E L C R} \times 10^{3}}
\end{aligned}
$$

where $E L C R$ is the carcinogenic risk associated with As exposure for fish ingest; $H Q$ is the non-carcinogenic risk for each heavy metal; $H I$ is a hazard index that may result in additive and/or interactive effects of different heavy metal to non-carcinogenic risk (Li et al. 2013, Zaha and Zaman 2013); C (mg/kg) is the heavy metal concentration in flesh muscle (we assumed that a worse scenario [potential risk] is bond to the maximal concentration tested [US-EPA 2006], while the expected scenario [real risk] is related with the average concentration tested [Giri and Singh 2014]); $E D_{\mathrm{ELCR}}$ is a lifetime record in Cuba population, fixed in 76 years for men and 80 years for women (INE 2019); $E D_{\mathrm{HQ}}$ is a time of exposure fixed in 30 years for adults (US-EPA 2006); DI (g/day) is the daily fish intake; $E F_{\mathrm{r}}$ (day/year) is the frequency of exposure; $A T_{\mathrm{ELCR}}$ and $A T_{\mathrm{HQ}}$ are a number of days corresponding to $E D_{\mathrm{ELCR}}$ and $E D_{\mathrm{HQ}}$, respectively; $C S F_{O}<$ is this subscript a zero or an o? (and all the others in these formulas) $>$ is the slope factor for As from the Integrated Risk Information System (IRIS) database provided by USEPA ( $1.5 \mathrm{mg} / \mathrm{kg} / \mathrm{day}) ; R f D o$ is the oral reference doses for each metal from the IRIS database: $1 \times 10^{-3}, 4 \times 10^{-2}, 3.5 \times 10^{-3}, 3 \times$ $10^{-1}$, and $3 \times 10^{-4} \mathrm{mg} / \mathrm{kg} /$ day for $\mathrm{Cd}, \mathrm{Cu}, \mathrm{Pb}, \mathrm{Zn}$, and inorganic As, respectively (US-EPA 2010) (it is necessary to clarify that for estimating HI and ELCR we assumed that that the first ingested dose was equal to the absorbed pollutant dose and cooking had no effect on the pollutants [US-EPA 2006]); $B W_{\mathrm{msC}}$ is the average body weight value for Cuban population considering a significant difference between genera: $61.3 \mathrm{~kg}$ for women and $69.6 \mathrm{~kg}$ for men (INE 2019); and $B W_{\mathrm{a}}(\mathrm{kg})$ is the weigh body in each people tested.

Data for local variations (unknown or unpublished) of $B W_{\mathrm{a}}, D I$, and $E F_{\mathrm{r}}$ were obtained using a survey method (Giri and Singh 2014) in the influence area of the Pedroso dam.
The minimal sample dimension for $95 \%$ confidence $\left(n_{\mathrm{h}}\right)$ was obtained using the criterion of Cochran (1981) in three of the studied towns with total population $N_{\mathrm{h}}<2000$ inhabitants. In the remaining two studied towns, with $N_{\mathrm{h}}>4000$ inhabitants each, the used criterion to established $n_{\mathrm{h}}$ was to survey $10 \%$ of $N_{\mathrm{h}}$. The total population survey was 2939 inhabitants from a total $23733(12.38 \%)$. The risk assessment calculations were performed for each person separately and were subsequently grouped in a frequency graph to illustrate the potential and actual risks for different consumption patterns.

\section{RESULTS AND DISCUSSION}

\section{Heavy metal concentrations in water of the Pe- droso dam and its tributaries}

The mean heavy metal content, standard deviations and ranges determined in water samples from the Ganuza and Mampostón rivers, as well as the Pedroso reservoir are reported in table I. The order of mean metal concentration in water is different in each studied ecosystem: $\mathrm{Zn}>\mathrm{Pb}>\mathrm{Cr}>\mathrm{Cu}>\mathrm{As}>$ $\mathrm{Co}>\mathrm{Cd}$ in the Ganuza river; $\mathrm{Pb}>\mathrm{Zn}>\mathrm{Cr}>\mathrm{Cu}>$ $\mathrm{As}>\mathrm{Co}>\mathrm{Cd}$ in the Mampostón river, and $\mathrm{Zn}>\mathrm{Cr}$ $>\mathrm{Cu}>\mathrm{Pb}>\mathrm{As}>\mathrm{Co}>\mathrm{Cd}$ in the Pedroso reservoir.

The largest ranges (maximum to minimum content ratio > 10) were observed only for $\mathrm{Pb}$ levels in Ganuza and Mampostón rivers. Its mean $\mathrm{Pb}$ contents exceed the permissible levels established for drinking water by Cuban (ONN 2017), US-EPA (2010) and WHO (2008) regulations. The highest Pb concentrations were measured in water samples from stations G4 $(85.5 \mu \mathrm{g} / \mathrm{L}), \mathrm{M} 2(35.1 \mu \mathrm{g} / \mathrm{L})$ and M3 $(345.8 \mu \mathrm{g} / \mathrm{L})$. Therefore, the $\mathrm{Pb}$ content accumulated by decades in soils around the asphalt factory (station M2) and national highway (station M3) must have been dragged by rain, wind or human activities, and subsequently deposited in those river areas. On the other hand, lead was an important raw material in the production paints for many years. A poor operation of the paint factory (station G4) sewage system could be the cause of $\mathrm{Pb}$ accumulation in that area of the Ganuza River.

\section{Heavy metal concentrations in edible fish muscle from the Pedroso dam}

Metal concentrations in the edible muscle of the three investigated fish species from the Pedroso reservoir are shown in table II. The order of mean metal concentration in edible muscle is different for each of studied species: $\mathrm{Zn}>\mathrm{Cu}>\mathrm{Cd}>\mathrm{Pb}>\mathrm{Cr}>\mathrm{As}$ 
TABLE I. HEAVY METAL CONTENT IN THE STUDIED WATERS (MEAN \pm SD), RANGES AND PERMISSIBLE LIMITS $(\mu \mathrm{g} / \mathrm{L})$.

\begin{tabular}{|c|c|c|c|c|c|c|}
\hline & $\begin{array}{l}\text { Ganuza } \\
\text { river }\end{array}$ & $\begin{array}{l}\text { Mampostón } \\
\text { river }\end{array}$ & $\begin{array}{l}\text { Pedroso } \\
\text { reservoir }\end{array}$ & $\begin{array}{l}\text { ONN } \\
(2017)\end{array}$ & $\begin{array}{l}\text { US-EPA } \\
(2009)\end{array}$ & $\begin{array}{l}\text { WHO } \\
(2008)\end{array}$ \\
\hline $\mathrm{Cr}$ & $\begin{array}{l}20.9 \pm 20.5 \\
(6.9-50.9)\end{array}$ & $\begin{array}{c}7.6 \pm 1.8 \\
(5.5-10.2)\end{array}$ & $\begin{array}{c}9.9 \pm 5.1 \\
(5.5-17.1)\end{array}$ & N.A. & 100 & 50 \\
\hline $\mathrm{Co}$ & $\begin{array}{c}0.3 \pm 0.2 \\
(0.1-0.4)\end{array}$ & $\begin{array}{c}1.2 \pm 2.5 \\
(0.1-5.7)\end{array}$ & $\begin{array}{c}0.2 \pm 0.1 \\
(0.1-0.4)\end{array}$ & N.A. & 5 & N.A. \\
\hline $\mathrm{Cu}$ & $\begin{array}{c}8.1 \pm 1.3 \\
(7.2-9.9)\end{array}$ & $\begin{array}{c}3.8 \pm 1.9 \\
(1.9-5.4)\end{array}$ & $\begin{array}{c}4.3 \pm 0.8 \\
(3.9-5.6)\end{array}$ & 1000 & 1300 & 2000 \\
\hline $\mathrm{Zn}$ & $\begin{array}{c}28.7 \pm 16.8 \\
(11.0-43.5)\end{array}$ & $\begin{array}{l}18.1 \pm 12.3 \\
(6.9-36.3)\end{array}$ & $\begin{array}{c}43.1 \pm 28.7 \\
(21.2-81.7)\end{array}$ & 5000 & 5000 & 5000 \\
\hline As & $\begin{array}{c}0.6 \pm 0.4 \\
(0.2-0.9)\end{array}$ & $\begin{array}{c}0.6 \pm 0.2 \\
(0.4-0.7)\end{array}$ & $\begin{array}{c}0.6 \pm 0.1 \\
(0.5-0.7)\end{array}$ & 10 & 10 & 10 \\
\hline $\mathrm{Cd}$ & $\begin{array}{c}0.02 \pm 0.01 \\
(0.02-0.03)\end{array}$ & $\begin{array}{c}0.06 \pm 0.04 \\
(0.03-0.11)\end{array}$ & $\begin{array}{c}0.16 \pm 0.26 \\
(0.02-0.54)\end{array}$ & 3 & 5 & 3 \\
\hline $\mathrm{Pb}$ & $\begin{array}{l}24.2 \pm 40.9 \\
(1.3-85.5)\end{array}$ & $\begin{array}{l}82.2 \pm 147.8 \\
(9.6-345.8)\end{array}$ & $\begin{array}{c}1.8 \pm 0.3 \\
(1.5-2.3)\end{array}$ & 10 & 15 & 10 \\
\hline
\end{tabular}

TABLE II. HEAVY METALS CONTENTS IN EDIBLE MUSCLE OF THE STUDIED FISH SPECIES (MEAN \pm SD). RANGES AND PERMISSIBLE LIMITS ( $\mathrm{mg} / \mathrm{kg}$ ww).

\begin{tabular}{|c|c|c|c|c|c|c|}
\hline & $\begin{array}{c}\text { Tilapia } \\
\text { (Oreochromis spp.) }\end{array}$ & $\begin{array}{c}\text { Tench } \\
\text { (Tinca tinca) }\end{array}$ & $\begin{array}{c}\text { Catfish } \\
\text { (Clarias gariepinus) }\end{array}$ & $\begin{array}{l}\text { ONN } \\
(2015)\end{array}$ & $\begin{array}{l}\text { US-EPA } \\
(2010)\end{array}$ & $\begin{array}{c}\mathrm{EC} \\
(2001)\end{array}$ \\
\hline $\mathrm{n}$ & 43 & 16 & 19 & & & \\
\hline Length $(\mathrm{cm})$ & $11.0-17.8$ & $20.5-30.1$ & $23.0-44.3$ & & & \\
\hline Weight (g) & $61.4 \pm 21.6$ & $168 \pm 14$ & $283 \pm 138$ & & & \\
\hline $\mathrm{Cr}$ & $\begin{array}{l}0.18 \pm 0.13 \\
(0.03-0.52)\end{array}$ & $\begin{array}{l}0.21 \pm 0.10 \\
(0.06-0.58)\end{array}$ & $\begin{array}{l}0.10 \pm 0.06 \\
(0.01-0.25)\end{array}$ & & & \\
\hline Co & $\begin{array}{l}0.13 \pm 0.13 \\
(0.01-0.42)\end{array}$ & $\begin{array}{l}0.14 \pm 0.20 \\
(0.06-0.58)\end{array}$ & $\begin{array}{l}0.06 \pm 0.07 \\
(0.01-0.25)\end{array}$ & & 0.41 & \\
\hline $\mathrm{Cu}$ & $\begin{array}{l}0.65 \pm 0.26 \\
(0.23-1.30)\end{array}$ & $\begin{array}{l}0.68 \pm 0.37 \\
(0.25-1.52)\end{array}$ & $\begin{array}{c}13.69 \pm 32.08 \\
(0.86-88.16)\end{array}$ & & 54 & \\
\hline $\mathrm{Zn}$ & $\begin{array}{l}19.4 \pm 9.2 \\
(6.8-29.9) \\
\end{array}$ & $\begin{array}{c}8.6 \pm 8.3 \\
(4.9-29.8)\end{array}$ & $\begin{array}{l}14.6 \pm 5.4 \\
(5.5-20.0) \\
\end{array}$ & & 410 & \\
\hline As & $\begin{array}{l}0.18 \pm 0.22 \\
(0.01-0.86)\end{array}$ & $\begin{array}{l}0.13 \pm 0.13 \\
(0.01-0.36)\end{array}$ & $\begin{array}{l}0.10 \pm 0.10 \\
(0.01-0.27)\end{array}$ & 1.0 & 0.41 & \\
\hline $\mathrm{Cd}$ & $\begin{array}{l}0.29 \pm 0.25 \\
(0.02-2.13)\end{array}$ & $\begin{array}{l}0.53 \pm 0.85 \\
(0.03-2.93)\end{array}$ & $\begin{array}{l}0.09 \pm 0.13 \\
(0.02-0.45)\end{array}$ & 0.1 & 1.4 & 0.05 \\
\hline $\mathrm{Pb}$ & $\begin{array}{l}0.20 \pm 0.25 \\
(0.01-0.84)\end{array}$ & $\begin{array}{l}0.08 \pm 0.07 \\
(0.01-0.20)\end{array}$ & $\begin{array}{l}0.30 \pm 0.38 \\
(0.03-1.23)\end{array}$ & 0.3 & & 0.2 \\
\hline
\end{tabular}

$>$ Co for tilapia, $\mathrm{Zn}>\mathrm{Cu}>\mathrm{Cd}>\mathrm{Cr}>\mathrm{Co}>\mathrm{As}>\mathrm{Pb}$ for tench, and $\mathrm{Zn}>\mathrm{Cu}>\mathrm{Pb}>\mathrm{Cr}>\mathrm{As}>\mathrm{Cd}>\mathrm{Co}$ for catfish. The comparison with Cuban, USA and EC regulations (Table II) shows that concentrations for most of the metals in the studied fish species were found to be safe for human consumption.

However, the Cd content in muscles from 44, 37.5 , and $40 \%$ of the studied tilapia, tench and 
catfish, respectively, exceeded the Cd permissible levels established by Cuban regulations; by the USA regulations by 2.2 and $6.7 \%$ for tilapia and tench, respectively; and the EC regulations by $44,37.5$ and $58 \%$ for tilapia, tench and catfish, respectively. On the other hand, 14 and $23 \%$ of the studied tilapias and 20 and $32 \%$ of catfishes, exceed the Cuban and $\mathrm{EC}$ permissible $\mathrm{Pb}$ levels, respectively. Furthermore, the $\mathrm{Cu}$ content measured in $16 \%$ of the studied catfishes exceed the US permissible levels for human consumption.

By comparing the measured mean content of the most hazardous metals ( $\mathrm{As}, \mathrm{Cd}$ and $\mathrm{Pb}$ ) with similar worldwide studies previously reported (Table III), and considering the descending order of heavy metals that represent a risk to human health (As $>\mathrm{Pb}>\mathrm{Cd}>\mathrm{Zn}>\mathrm{Cr}>\mathrm{Cu}>\mathrm{Co}$ ) according to the US Agency for Toxic Substances and Disease Registry (ATSDR 2013), it can be established that the metal content measured in fish species captured in the Pedroso reservoir is higher than the reported for clean areas (Has-Schön et al. 2008, Aktumsek and Gezgin 2011, Singh et al. 2012, Damodharan and Reddy 2013, Low et al. 2015, Mortuza and al-Misned 2015), and is more in correspondence with reports for polluted environments (Leung et al. 2014).

The bioaccumulation factor $(B A F>1)$ suggests the capability of each species to bioaccumulate heavy metals in its tissues. $\mathrm{Cu}$ is bioaccumulated in $C$. gariepinus fillets $\left(B A F_{(\mathrm{Cu})}=2.6\right)$, while $\mathrm{Cd}$ is bioaccumulated for all studied species in different proportions: tench $\left(B A F_{(\mathrm{Cd})}=6.6\right)$, tilapia $\left(B A F_{(\mathrm{Cd})}=\right.$ $3.6)$, and catfish $\left(B A F_{(\mathrm{Cd})}=1.2\right)$. This behavior is due to the feeding habits of these species and their mechanisms to interact with heavy metals. On the one hand, tilapia and tench follow a sediment-ingestion feeding behavior (Zhou et al. 1998, Kwok et al. 2014), which would directly impact their bioaccumulation levels for metals present in their living environment. On the other hand, catfish are a known trophic generalist (van Wassembergh et al. 2006); therefore, by ingesting smaller fishes of the area they also bioaccumulate heavy metals present in the sediments. In this sense, the study of metal contents in the Pedroso reservoir sediments is recommended.

\section{Population potential and real risk Pattern of fish consumption}

Of the total local population included in the survey, $32.1 \%$ (944 inhabitants) are consumers of fish captured in the Pedroso dam and its tributaries. It was found that a significant group of the surveyed people do not consume fish from the studied area due to four reasons: $(i)$ they never consume freshwater fishes $\left(n_{\mathrm{h}}\right.$ $29.3 \%$ ); (ii) they consume freshwater fishes from other locations ( $\left.n_{\mathrm{h}} 16.6 \%\right)$; (iii) they have information regarding the pollution status of the study area ( $\left.n_{\mathrm{h}} 12 \%\right)$; and (iv) they do not have access to local fish $\left(n_{\mathrm{h}} 10 \%\right)$.

Taking into consideration the differences between fish consumption patterns, local adult fish consumers must be divided into two groups: fishermen and their families, with an average fish consumption of $59.7 \pm$ $27.4 \mathrm{~g} /$ day $\left(n_{\mathrm{h}}=218\right)$; and general population, with an average fish consumption of $12.0 \pm 7.2 \mathrm{~g} /$ day $\left(n_{\mathrm{h}}\right.$ $=594)$. Frequency of consumption $\left(E F_{\mathrm{r}}\right)$ depends on the possibility to access this product, which is in average one time per week for general population and 2-3 times per week for fishermen families (Figure 2). In children, fish consumption pattern is practically the same for both groups. However, a difference in average fish consumption for different age groups was observed: $9.6 \pm 5.7 \mathrm{~g} /$ day in $2-5$ year-old children $\left(n_{\mathrm{h}}=23\right) ; 13.2 \pm 7.4 \mathrm{~g} /$ day in the $6-10$ year-old group $\left(n_{\mathrm{h}}=45\right)$; and $17.0 \pm 11.2 \mathrm{~g} /$ day in adolescents $\left(n_{\mathrm{h}}=\right.$ 64). Frequency of exposure $\left(E F_{\mathrm{r}}\right)$ in children remains almost constant, because all family members eat the same food at each meal (Figure 3).

\section{Risk exposure estimation}

Non-carcinogenic risk (HQ) exposure follows this order of heavy metal contribution to $\mathrm{HI}: \mathrm{Cu}$ $(54 \%)>\operatorname{As~}(22 \%)>\mathrm{Cd}(11 \%)>\mathrm{Pb}(7 \%)>\mathrm{Zn}$ (6\%). and C. gariepinus is the major contributor. Figures $\mathbf{2}$ and $\mathbf{3}$ show the histograms of hazard index, considering the daily intake in the influence area of the Pedroso dam. Usually, an HI value $<1$ is considered acceptable (US-EPA 2006, Jiang et al. 2016).

The above mentioned heavy metal fish content may induce gastrointestinal damage, neurological disorders and heart diseases. In that sense, the gastrointestinal no-observed-adverse-effects level (NOAEL) for $\mathrm{Cu}$ ingestion is $0.011 \mathrm{mg} / \mathrm{kg} / \mathrm{day}$, whereas cardiovascular and neurological NOAELs for $\mathrm{Cd}$ are 0.2 and $0.53 \mathrm{mg} / \mathrm{kg} /$ day, respectively. Hematological NOAEL for $\mathrm{Zn}$ is estimated in 0.3 $\mathrm{mg} / \mathrm{kg} /$ day (ATSDR 2013).

In adults the potential $\mathrm{HI}$ is evident when the daily intake is higher than $23 \mathrm{~g}$ /day (worst case scenario). In this case, $38.6 \%$ of the surveyed population is at risk of expressing non-carcinogenic diseases due to intake exposure of heavy metals. The tolerable daily intake for real HI is estimated in $81 \mathrm{~g} /$ day. This is the equivalent of eating two fillets $(115 \mathrm{~g})$ with a frequency of 10 times per month. The daily intake 


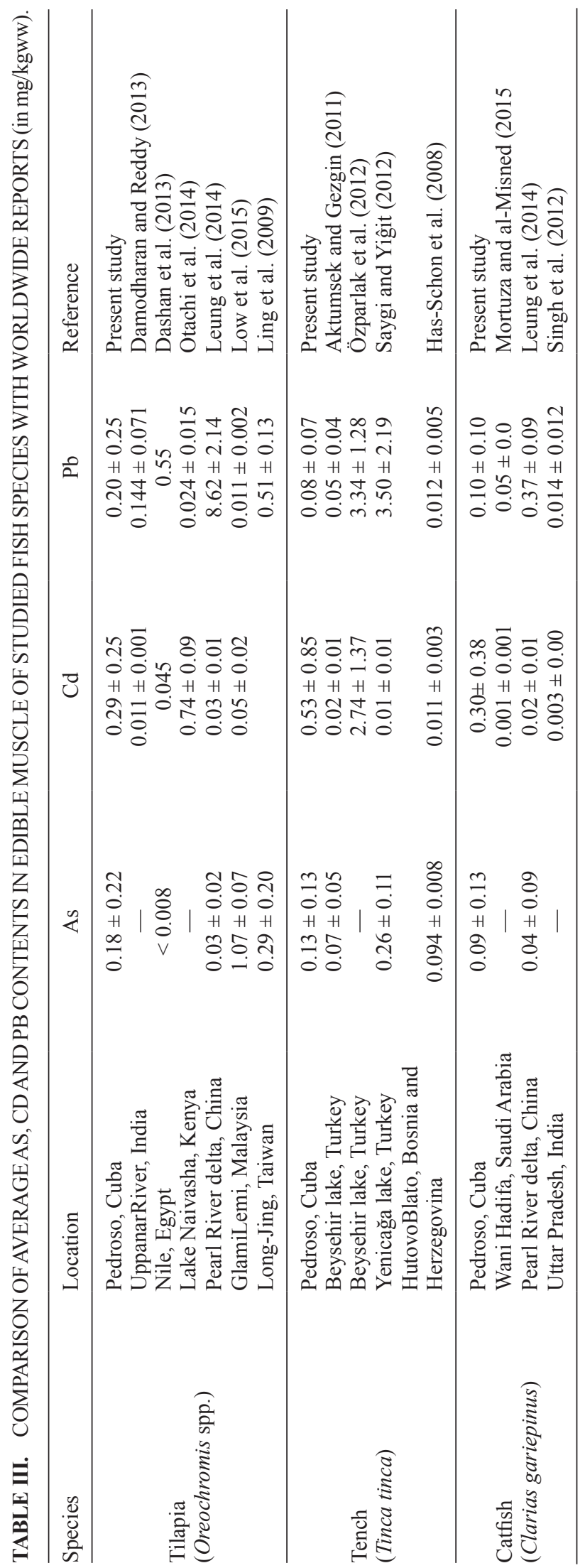




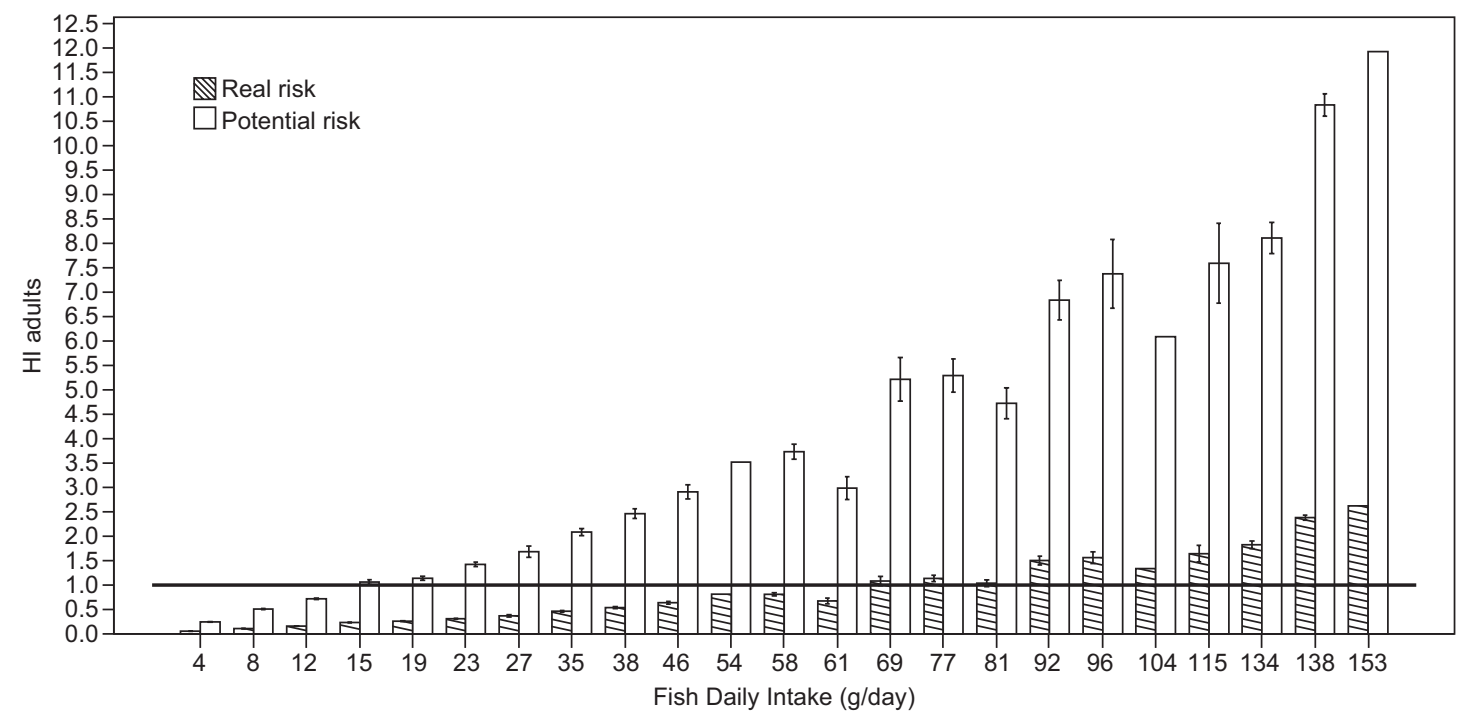

Fig. 2. Hazard index (HI) histograms in the influence area of the Pedroso dam. Vertical lines indicate variations in BWa for the daily intake of each fish class in adult population. The horizontal line represents tolerable HI levels $(<1)$.

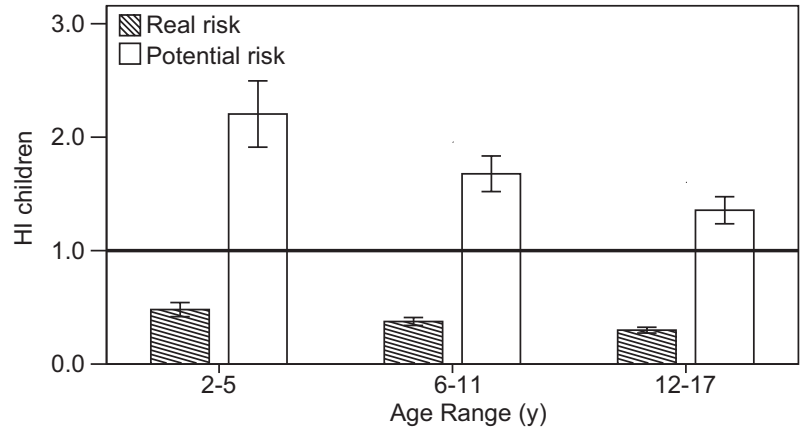

Fig. 3. Hazard index (HI) histograms in the influence area of Pedroso dam. Vertical lines indicate variations in BWa for each age group in children population. The horizontal line represents tolerable HI levels $(<1)$.

exceeded this $\mathrm{HI}$ value in 58 individuals of the surveyed population, all from the fishermen-families group, which suggests they may experience a certain degree of adverse health effects.

Potential $\mathrm{HI}$ is $>1$ in 56.6 and $31.25 \%$ of the $2-5$ and 6-10-year-old groups, respectively, and in 35.7\% of the teenagers. However, the actual HI is $<1$ for all of them. The tolerable daily intake in the worst scenario is estimated as follows for each class: $45 \mathrm{~g} /$ day for teenagers; $8 \mathrm{~g} /$ day for 6-10 year-olds and $4 \mathrm{~g} /$ day for 2-5 year-olds.

Carcinogenic risk for As exposure through fish ingestion is also shown in figures $\mathbf{4}$ and $\mathbf{5}$ (adults and children population, respectively). Cuba does not have any regulatory limits for ELCR. The acceptable levels in USA and Denmark are $1 \times 10^{-6}$. These levels may change in some cases like Germany $\left(5 \times 10^{-5}\right)$ and The Netherlands $\left(1 \times 10^{-4}\right)$, as shown in figure 4 . All of these limits are referred to potential risk, because the actual risk (albeit unknown) is unlikely to be higher and may well be very lower (Ferguson et al. 1998).

Regardless of the selected regulatory limit, the existence of potential and real carcinogenic risk in adult population is obvious. In adults and children, $95 \%$ of the ELCR normal distribution is equivalent to $5.8 \times 10^{-4}$ and $3.21 \times 10^{-4}$, respectively, following the methodology suggested by the US-EPA (2006) to establish a tolerable risk limit. These values suggest that some local children and adults can develop a cancer-related ailment during their lifetime due to As exposure, and all of them are related to fishermen families.

\section{CONCLUSION AND RECOMMENDATIONS}

Mean trace-elements concentrations in the water of the Pedroso dam and its tributaries reflected normal values, except in some stations from the Ganuza and Mampostón Rivers, associated with paint and asphalt factories and the national speedway, where $\mathrm{Pb}$ contents exceed the permissible levels established by Cuban and international regulations for drinking water. Additionally, the analysis of edible muscle in 


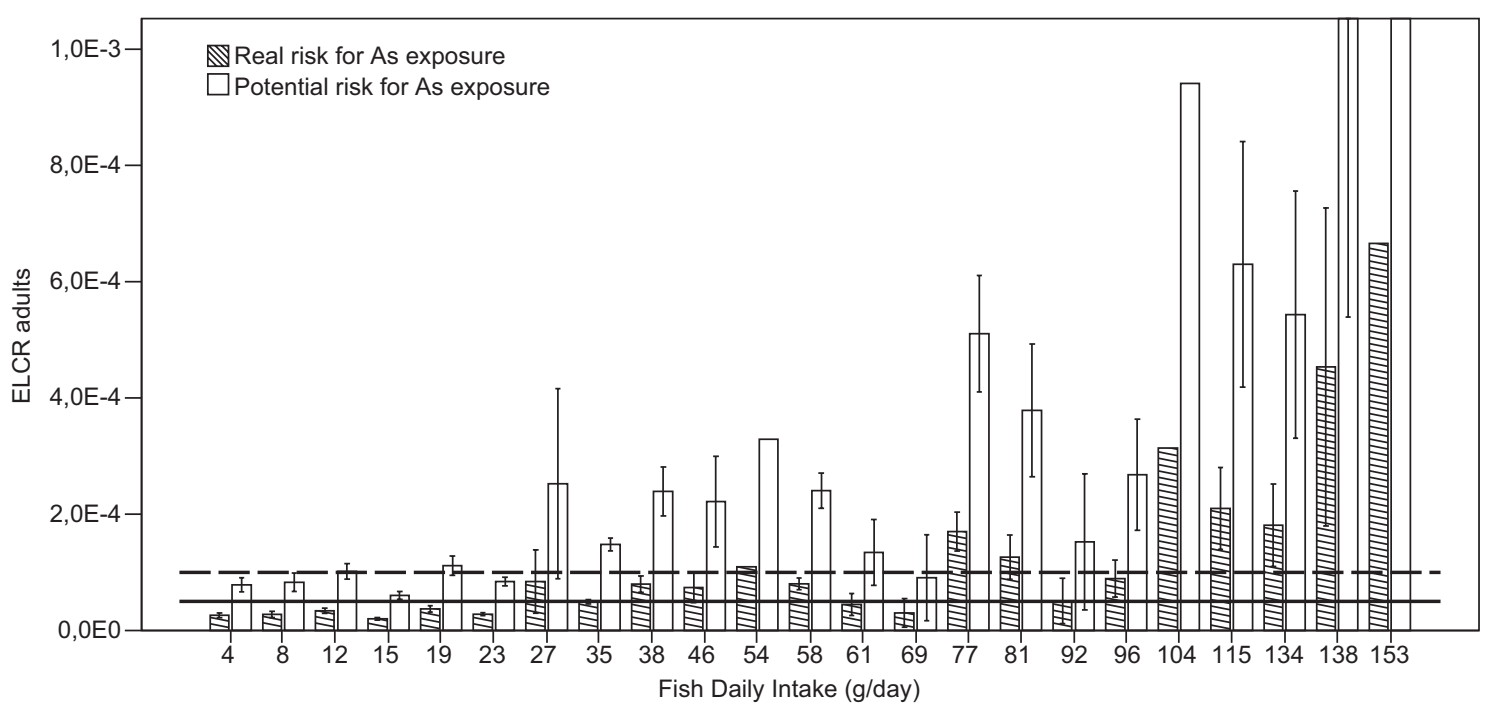

Fig. 4. Histograms ot carcinogenic risk due to As exposure (ELCR) in the influence area of the Pedroso dam. Verticals lines indicate variations in BWa for each class of fish daily intake in adult population. Horizontal lines represent accepted levels in Germany (continuous line) and Netherlands (dashed line).

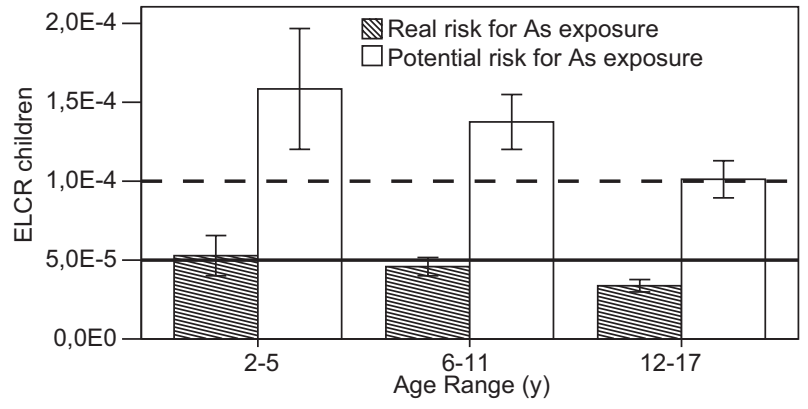

Fig. 5. Histograms of carcinogenic risk due to As exposure (ELCR) in the influence area of the Pedroso dam. Verticals lines indicated variations in BWa for each age group in children population. Horizontal lines represent accepted levels in Germany (continuous line) and Netherlands (dashed line).

three fish species (tilapia, tench and catfish) captured in the Pedroso dam, shows $\mathrm{Cd}, \mathrm{Pb}$, and $\mathrm{Cu}$ contents above the corresponding permissible levels established by Cuban and/or international regulations for human consumption.

Taking into account that obtained results show the metal bioaccumulation capability of the studied species and its probable impact on local population health (specially on children), it is necessary to include this information in the water resources management plan for the Pedroso dam, in order to control the capture and commercialization of fishes, local industries wastes and illegalities. On the other hand, taking into account that water from the Pedroso reservoir is pumped towards the Mampostón reservoir, the metal content analysis in edible muscle of fish farmed in the latter is also recommended.

\section{ACKNOWLEDGMENTS}

The authors express sincere gratitude to all families who voluntarily participated in the survey. Also, we appreciate the collaboration of all technicians and specialists from the EcoLab laboratory (Toulouse, France) for their professionalism and dedication to carry out this work.

\section{REFERENCES}

Agah H., Leemakers M., Elskens M., Fatemi S.M.R. and Baeyens W. (2009). Accumulation of trace metals in the muscles and liver tissues of five fish species from the Persian Gulf. Environ. Monit. Assess. 157, 499-514. https://doi.org/10.1007/s10661-008-0551-8

Aktumsek A. and Gezgin S. (2011). Seasonal variations of metal concentrations in muscle tissue of tench (Tinca tinca), water and sediment in Beysehir Lake (Turkey). Environ. Technol. 32 (13), 1479-1485. https://doi.org/ 10.1080/09593330.2010.540717

ATSDR (2013). Priority list of hazardous substances. Agency for Toxic Substances and Disease Registry, Atlanta, Georgia, USA [on line]. https://www.atsdr. cdc.gov/spl/index.html 12/12/2019 
Canpolat Ö., Eroĝlu M., Coban M.Z. and Düşükcan M. (2014). Transfer factors and bioaccumulation of some heavy metals in muscle of a freshwater fish species: A human health concern. Fresenius Environ. Bull. 23 (2), 418-425.

Cochran W. (1981). Técnicas de muestreo. 2a imp. Compañía Editorial Continental, Mexico, 58 pp.

Dahshan H., Abd-Elall A.M.M. and Megahed A.M. (2013). Trace metal levels in water, fish, and sediment from River Nile, Egypt: Potential Health Risks Assessment. J. Toxicol. Env. Heal. A 76 (21), 1183-1187. https:// doi.org/10.1080/15287394.2013.848421

Damodharan U. and Reddy M. (2013). Heavy metal bioaccumulation in edible fish species from an industrially polluted river and human health risk assessment. Arch. Pol. Fish 21, 19-27. https://doi.org/10.2478/ aopf-2013-0003

EC. (2001). Setting maximum levels for certain contaminants in foodstuffs. Commission Regulation No. 466/2001, OJEC L77/1. The Commission of European Communities: Official Journal of the European Communities [on line]. https:/op.europa.eu/en/ publication-detail/-/publication/52b2484d-39e0-4aa9ba19-4b13a887bb1c 13/11/2019

Erdoĝrul Z. and Ates D.A. (2006). Determination of cadmium and copper in fish samples from Sir and Menzelet dam lake Kahramanmaras, Turkey. Environ. Monit. Assess. 117, 281-290. https://doi.org/10.1007/ s10661-006-0806-1

Ferguson C., Darmendrail D., Freier K., Jensen B.K., Jensen J., Kasamas H., Urzelai A. and Vegter J., eds. (1998). Risk assessment for contaminated sites in Europe. Vol. 1. Scientific Basis. LQM Press, Nottingham, 165 pp.

Giri S. and Singh A.K. (2014). Assessment of human health risk for heavy metals in fish and shrimp collected from Subarnarekha River, India. Int. J. Environ. Heal. R. 24 (5), 429-449. https://doi.org/10.1080/09603123.2013.857391

Has-Schön E., Bogut I., Rajković V., Bogut S., Čačić M. and Horvatić J. (2008). Heavy metal distribution in tissues of six fish species included in human diet, inhabiting freshwaters of the nature park "Hutovo Blato" (Bosnia and Herzegovina). Arch. Environ. Contam. Toxicol. 54, 75-83. https://doi.org/10.1007/ s00244-007-9008-2

Huang Y., Lin K., Chen H., Chang C.C., Liu C.W., Yang M.H. and Hsueh Y.M. (2003). Arsenic species contents at aquaculture farm and in farmed mouthbreeder (Oreochromis mossambicus) in BFD hyper endemic areas. Food. Chem. Toxicol. 41 (1), 1491-1500. https://doi. org/10.1016/S0278-6915(03)00165-0

INE (2019). Anuario estadístico de Cuba. Instituto Nacional de Estadísticas, Havana, Cuba [on line]. http:// www.onei.gob.cu/node/14211 12/12/2019
Jiang H., Qin D.L., Chen Z., Tang S.Z., Bai S.Y. and Mou Z.B. (2016). Heavy metal levels in fish from Heinlongjiang River and potential health risk assessment. Bull. Environ. Contam. Toxicol. 97 (4), 536-542. https://doi.org/10.1007/s00128-016-1894-4

Kwok C.K., Liang Y., Wang H., Dong Y.H., Leung S.Y. and Wong M.H. (2014). Bioaccumulation of heavy metals in fish and Ardeid at Pearl River Estuary, China. Ecotoxicol. Environ. Saf. 106, 62-67. https:// doi.org/10.1016/j.ecoenv.2014.04.016

Leung H.M., Leung A.O.W., Wang H.S., Ma K.K., Liang Y., Ho K.C., Cheung K.C., Tohidi F. and Yung K.K.L. (2014) Assessment of heavy metals/metalloid (As, Pb, $\mathrm{Cd}, \mathrm{Ni}, \mathrm{Zn}, \mathrm{Cr}, \mathrm{Cu}, \mathrm{Mn}$ ) concentrations in edible fish species tissue in the Pearl River Delta (PRD), China. Mar. Poll. Bull. 78, 235-245. https://doi.org/10.1016/j. marpolbul.2013.10.028

Li J., Huang Zh.Y., Hu Y. and Yang H. (2013). Potential risk assessment of heavy metals by consuming shellfish collected from Xiamen, China. Environ. Sci. Pollut. Res. 20 (5), 2937-2947 [on line]. https://www.ncbi. nlm.nih.gov/pubmed/23054773 18/09/2019

Lima L., López-Heras M.I., Pedrero Z., OlivaresRieumont S., Madrid Y., Cámara C. and de la Rosa D. (2013). Levels of arsenic, mercury and selenium in Clarias gariepinus from Sagua la Grande River, Cuba. Ann. Limnol-Int. J. Lim. 49, 113-119. https:// doi.org/10.1051/limn/2013046

Ling M.P., Hsu H.T., Shie R.H., Wu C.C. and Hong Y.S. (2009). Health risk of consuming heavy metals in farmed tilapia in central Taiwán. Bull. Environ. Contam. Toxicol. 83, 558-564.https://doi.org/10.1007/s00128-009-9829-y

Low K.H., Zain S.M., Abas M.R., Salleh K.M. and Teo Y.Y. (2015). Distribution and health risk assessment of trace metals in freshwater tilapia from three different aquaculture sites in Jelebu Region (Malaysia). Food Chem. 177, 390-396. https://doi.org/10.1016/j. foodchem.2015.01.059

MIP (2008). Informe técnico de pesca en embalses de La Habana. Ministerio de la Industria Pesquera, Havana, Cuba, 25 pp.

Monroy M., Maceda-Veiga A. and de Sostoa A. (2014). Metal concentration in water, sediment and four fish species from Lake Titicaca reveals a large-scale environmental concern. Sci. Total Environ. 487, 233-244. https://doi.org/10.1016/j.scitotenv.2014.03.134

Mortuza M.G. and al-Misned F.A. (2015). Heavy metal concentration in two freshwater fishes from Wadi Hanifah (Riyadh, Saudi Arabia) and evaluation of possible health hazard to consumers. Pakistan J. Zool. 47 (3), 839-845.

ONN (2015). NC 493: 2015. Contaminantes metálicos en alimentos. Regulaciones sanitarias. Oficina Nacional 
de Normalización, Havana, Cuba [on line]. https:// sistemas.mre.gov.br/kitweb/datafiles/Havana/pt-br/ file/NC\%20493\%202015\%20Contaminantes $\% 20$ metalicos(1).pdf 01/10/2019

ONN (2017). NC 827: 2017. Agua potable. Requisitos sanitarios. Oficina Nacional de Normalización, Havana, Cuba [on line]. http://www.cgdc.cu/sites/default/ files/nc_827.pdf 01/10/2019

Otachi E.O., Körner W., Avenant-Oldewage A., Felner-Frank C. and Jirsa F. (2014). Trace elements in sediments, blue spotted tilapia Oreochromi sleucostictus (Trewavas, 1933) and its parasite Contracaecum multipapillatum from Lake Naivasha, Kenya, including a comprehensive health risk analysis. Environ. Sci. Pollut. Res. 21, 73397349. https://doi.org/10.1007/s11356-014-2602-8

Özparlak H., Gülşin A.G. and Arslan E. (2012). Determination of some metal levels in muscle tissue of nine fish species from Beyşehirlake, Turkey. Turkish J. Fish Aquatic Sci. 12, 761-770. https://doi. org/10.4194/1303-2712-v12_4_04

Saygi Y. and Yighit S.A. (2012). Assessment of metal concentrations in two cyprinid fish species (Leuciscus cephalus and Tinca tinca) captured from Yeniçağalake, Turkey. Bull. Environ. Contam. Toxicol. 89, 86-90. https://doi.org/10.1007/s00128-012-0647-2

Singh A.K., Srivastava S.C., Ansari A. and Kumar S.R. (2012). Environmental monitoring and health risk assessment of African catfish Clarias gariepinus (Burchell, 1822) cultured in rural ponds, India. Bull. Environ. Contam. Toxicol. 89, 1142-1147. https://doi. org/10.1007/s00128-012-0860-Z

US-EPA (2006). EPA region III risk-based concentration table: Technical background information. United States Environmental Protection Agency [on line]. https:// hwbdocuments.env.nm.gov/Los\%20Alamos $\% 20$ National\%20Labs/References/9642.PDF 07/07/2019

US-EPA (2009). United States Environmental Protection Agency. National recommended water quality criteria.
Washington DC, USA. [on line]. http://water.epa. gov/scitech/swguidance/standards/ criteria/current/. 05/07/2018.

US-EPA (2010). Risk-based concentration table. United States Environmental Protection Agency [on line]. http://www.epa.gov/reg3hwmd/risk/human/index. htm 05/07/2018

Van Wassenbergh S., Herrel A., Adriaens D. and Aerts P. (2006). Modulation and variability of prey capture kinematics in clariid catfishes. J. Exp. Zool. 305A, 559-569. https://doi.org/10.1002/jez.a.293

Wang S., Lin K., Hsueh Y. and Liu C. (2007). Arsenic distribution in a tilapia (Oreochromis mossambicus) water-sediment aquacultural ecosystem in blackfoot disease hyperendemic areas. Bull. Environ. Contam. Toxicol. 78, 147-151. https://doi.org/10.1007/s00128007-9013-1

WHO (2008). Guidelines for drinking-water quality. Vol. 1: Recommendations. 3rd ed. World Health Organization, Geneva, Switzerland, 668 pp. [on line]. https:// www.who.int/water_sanitation_health/publications/ drinking-water-quality-guidelines-4-including-1 staddendum/en/ 14/07/2019

Yi Y.J. and Zhang S.H. (2012). Heavy metal (Cd, Cr, Cu, $\mathrm{Hg}, \mathrm{Pb}, \mathrm{Zn}$ ) concentrations in seven fish species in relation to fish size and location along the Yangtze River. Environ. Sci. Pollut. Res. 19, 3989-3996. https://doi. org/10.1007/s11356-012-0840-1

Zaha N. and Zaman M.R. (2013). Evaluation of possible health risks of heavy metals by consumption of foodstuffs available in the central market of Rajshahi City, Bangladesh. Environ. Monit. Assess. 185, 3867-3878. https://doi.org/10.1007/s10661-012-2835-2

Zhou H.Y., Cheung R.Y.H., Chan K.M. and Wong M.H. (1998). Metal concentrations in sediments and tilapia collected from inland waters of Hong Kong. Water Res. 32, 3331-3340. https://doi.org/10.1007/s10661008-0624-8 